Kerstin Rydbeck and Jamie Johnston

\title{
2 LAM institutions: a Cross-country Comparison of Legislation and Statistics on Services and Use
}

\section{Introduction}

Many factors influence the ability of libraries, archives, and museums (LAM) to fulfil their role as public sphere institutions. This chapter aims to give an overview of the current situation of LAM institutions in the partnering countries of the ALMPUB research project by reviewing the legislation and the national statistics on services and use. The overarching purpose is to provide a background for the following chapters written by researcher partners from the participating countries. The countries included in the project are Norway, Sweden, Denmark, Germany, Switzerland, Hungary, and to some extent Iceland and Poland, which were not part of the initial research team.

This chapter has separate sections on libraries, archives, and museums. These sections include overviews of the purpose statements in the legislative acts in the participating countries, the methods used to collect national statistics, and the national statistics on services and use across the countries. Lastly, a broad comparison is made of the LAM institutions in the summarizing discussion.

The collection of national LAM statistics presents various methodological challenges when attempting to make comparisons across countries; however, these challenges can also be seen as a part of the result. The aims and focus differ widely across countries and across the three sectors. The statistics gathered, or not gathered, have implications about what is deemed important as well as about whether the respective sectors can be regarded as part of a common field of practice. The statistics and information about LAM legislation in the eight countries are presented in Table 2.1 (see appendix). Unless otherwise indicated, the information in the text is based on Table 2.1. Links to legislative documents and national statistics are included in the reference list.

\section{Public Library Legislation}

The International Federation of Library Associations and Institutions (IFLA) defines a public library as “an organization established, supported and funded by 
the community, either through local, regional or national government or through some other form of community organization. It provides access to knowledge, information and works of the imagination through a range of resources and services and is equally available to all members of the community" (The Public Library Service 2001). This definition can be seen as describing the core functions of public libraries, however many libraries have taken on an expanded role as a result of their own initiative or of country-specific legislation.

Public libraries are legislated to a far greater degree than archives and museums. Of the participating countries, Norway, Sweden, Denmark, Iceland, Poland, and Hungary have library laws, whereas only Germany and Switzerland do not. In Germany, some of the federal states have legislation that describes the role of public libraries, but without any statutory duty, funding requirements or regulation of mission fulfillment. Public libraries are defined as non-compulsory municipal services. The first of the 16 German states (Bundesländer) to establish a library law was Thüringen in 2008. This was preceded by a law in 1969 that established the mission of the national library, which was revised after the reunion in 2006. Switzerland does not have a library law at any level of government. Combination libraries appear to be more common in Switzerland than in the other participating countries. This prevalence of combination libraries may complicate attempts to establish public-library specific legislation.

The social missions or purposes stated in the library laws vary across the different countries. Democracy and the formation of an educated and informed citizenry are central themes in all the library laws in the participating countries. In Norway, the purpose of libraries is to promote information, education, and other cultural activities and serve as independent meeting places and arenas for discussion and debate; thus, the law can be seen as primarily focusing on the fostering of an inclusive and informed public discourse or sphere. Furthermore, it is stated in the Norwegian Public Library Act (2013) that library materials should be free to anyone living in the country, which can be interpreted as the promotion of equality and equal opportunity. Lastly, it states that the individual library must emphasize quality, versatility, and timeliness in its offerings to children and adults and make the materials and services known, which can be understood as tasking libraries to serve and represent all groups in society.

The Swedish Library Act (2013) applies to all types of libraries. The law states that libraries shall promote the development of democratic society by contributing to the dissemination of knowledge and the freedom of opinion. Furthermore, it states that libraries are to promote literature and interest in education, information and research, and cultural activities in general. Lastly, it states that library activities should be available to everyone, thus including the promotion of equality and inclusivity. 
Danish Library Act (2000) states the purpose of public libraries is to promote information, education, and cultural activity by making available books, periodicals, talking books, and other suitable material, such as recorded music and electronic information resources, including Internet and multimedia and videos. Libraries also shall promote municipal and government information and information about society in general; thus, the law can be seen as focusing on the promotion and support of citizenship and an informed citizenry. Furthermore, it states that the objective of the public libraries shall be achieved by observing quality, comprehensiveness, and topicality in the selection of materials, and that these criteria alone must be the decisive factors and not any religious, moral, or political views of the staff. The obligation to be impartial can be seen to relate, again, to the library's role in the promotion and establishment of equality and inclusivity; thus democracy.

The Libraries Act of Iceland (2013) applies to all types of libraries and states that the common goal of libraries is to equalize access to culture and knowledge through the provision of diverse collections and information in various forms and the promotion of cultural and scientific activities, education, lifelong learning, work life, Icelandic language, reading for pleasure, and information literacy. It also states that emphasis should be placed on libraries' collections reflecting as many views as possible. Collectively, this can be seen as supporting democracy through equality and and inclusion.

The Polish Library Act (1997) in Chapter 5 on public libraries states that public libraries are to meet the educational, cultural, and information needs of the general public and participate in the dissemination of knowledge and culture as well as preserve the national heritage by organizing and providing access to Polish works. The premise that libraries are for everyone and that they are to provide information and preserve the cultural heritage again relates to the promotion of equality and inclusion.

The Hungarian Library and Museum Act (1997) states that the institutions' aims are the preservation of national cultural traditions and those of national and ethnic minorities, their worthy continuation, improving the staffing, intellectual and economic conditions for community and individual general cultural activities, and promoting value-oriented activities aimed at improving citizens' quality of life. It also states that freedom of access to information for all is a fundamental condition for the functioning of the information society and the democratic constitutional state, thus explicitly establishing libraries and museums as fundamental to democracy. This is the only law that combines museums and libraries together, which can be seen as giving them a shared social role and possibly as placing them within a common sector. 
Access to information is stated in each of the acts, however, only the library acts in Hungary and Sweden state the promotion of democracy as part of the social mission or role of public libraries, although the promotion and provision of access to information, culture, knowledge or a combination of these things can be seen as relating to the basic democratic principles of enlightened citizens and freedom of expression. Sweden is the only country that includes the promotion of active citizenship, though it is implied in the Danish law with the libraries' role in the promotion of municipal and government information and information about society in general.

All laws state something concerning the preservation or promotion of culture and cultural activities, however, Iceland, Hungary, and Poland are the only countries that explicitly state the preservation or promotion of the national language or culture; in Iceland, it is the Icelandic language and in Poland and Hungary, it is the national heritage. All the library laws require municipalities in the respective countries to offer a public library service. In some cases, municipalities can offer library services jointly with another municipality or type of library, such as a school or university library. The legal obligation for all municipalities to provide a library service can be seen as a high degree of structural support for their role as culture and information promoting institutions; however, there are many other factors that influence it, which can be seen in the statistics on services and use.

\section{Public Library Statistics}

Statistics provide a broad picture of whether the public funds invested in a library service lead to the desired results, for example, regarding the number of library visits or books loaned per year. Accordingly, there is an international ISO standard for library statistics that was developed in collaboration with IFLA ("ISO 2789:2013”). The fact that municipalities generally run the public libraries in the participating countries makes the collection of national statistics easy and, accordingly, almost all of the countries collect statistics that include all municipal library services regardless of size.

There are two exceptions, Iceland and Switzerland. In Iceland, the collection of statistical data pertaining to the LAM institutions was discontinued due to cuts in government spending after Iceland's financial crisis of 2008-2011. The main libraries in the different regions continued to collect statistics on their services and use. These are presented in Table 2.1. In Switzerland, the library statistics only include municipalities with 10,000 inhabitants and above. Some of the libraries are combination libraries, both public libraries and state (canton) libraries. The 
municipalities included in the national statistics represent a little over a third of Swiss libraries and these libraries are mainly located in the most densely populated areas. Consequently, the Swiss figures in Table 2.1 only give an approximate picture of the library services in the country and need to be interpreted with caution.

There are two other discrepancies in the statistics. The figures in Table 2.1 are all based on the 2017 library statistics; however, some of the figures from Denmark are not available for 2017 so figures for 2015 are used instead. The German figures only include participants in a voluntary survey; smaller libraries may be not included. To summarize, the differences noted above in the statistical data mean that the figures are not completely comparable. The figures do provide an overview of the situations in the participating countries and this allows for general comparisons across the countries.

\section{Public Libraries: Services and Use}

According to the figures in Table 2.1, Iceland is the country that allocates the most resources per capita for public libraries, followed by Denmark and Sweden; Switzerland comes forth and Norway fifth. However, Norway's figure only includes the resources for media and staff, which means that in reality the amount allocated is actually higher because the costs for and associated with the library premises need to be added in order to obtain a fully comparable figure.

Iceland stands out, not only because of its total resources per capita for public libraries, but also for the high number of physical access points and physical items per inhabitant. The relatively high figures may be in part a result of the low population density; each municipality must offer a library service, but there are fewer people per library service. The high total resources per capita may also be a result of the relatively high cost associated with the provision of public library services in the country. It is more costly to ship materials and other resources to Iceland than to countries located in mainland Europe. Salaries are also relatively high. The high figures for total running costs, number of access points and physical items per inhabitant may also indicate that Iceland gives a high level of priority to its library services.

The total number of library employees and items per inhabitant are relatively high in Poland and Hungary. Poland spends the least amount on library resources and staffing and Hungary the third lowest. The relatively high number of staff and physical items per inhabitant yet relatively low expenditure is likely a result of there being relatively lower salaries and cost of materials (e.g. book prices) in these two countries than in many of the other countries. 
Germany has the second lowest running costs per capita although the general levels of income are quite high. This means that the relatively high expenditures associated with staffing, compared to those in Poland and Hungary, yet low running costs must be balanced in some way. Consequently, Germany shows low figures for the number of full-time employees per 1,000 inhabitants, the number of physical service points per 1,000 inhabitants, and the number of physical items per inhabitant. The number of on-site visits per inhabitant is relatively low, however, Germany's figures regarding e-resource downloads (e.g. e-books) are high compared to other countries, with the exception of Denmark, although figures are not available for all countries. Public libraries in these two countries may have better solutions for downloading e-books and audiobooks than in the other countries. For example, in Denmark there are national agreements between the publishing houses and the public library sector. These types of agreements do not exist in the other countries or only to a limited extent, which makes the loaning of e-books more difficult for public libraries and may result in fewer downloads.

Intensity of library use can be obtained by comparing the number of borrowed items and library visits per capita with the numbers of physical items, employees, and physical access points. Accordingly, people in the Nordic countries appear to use their libraries more intensively than in the other countries, especially in comparison to library use in Hungary and Poland. Some ambiguity remains regarding the intensity of library use in Switzerland due to the way library statistics are collected in the country. However, the figure for the number of borrowed items is very high in relation to the figures for the number of physical items and number of visits per inhabitant in comparison to the Nordic countries, which suggests that the Swiss use their libraries just as or more intensively.

Hungary comes in second after Iceland for the most physical access points per inhabitant, which is still about three times more than in the other Nordic countries, yet Hungary has comparatively few library visits and loans per inhabitant. For example, Hungary's figures for library visits and loans are about a third of the Danish figures. Hungary's high number of service points per inhabitant may result from the administrative division of its municipalities. The country has more than 3,000 municipalities and more than half of them have less than 1,000 inhabitants. All municipalities regardless of size are required to provide a public library service that is operated by the county library. Interestingly, this relatively dense system does not result in intensive use.

Norway and Sweden have low population densities, though not to the same degree as Iceland. Low population density may result in a higher number of physical access points in relation to inhabitants so that the distance to the library does 
not hinder or prevent use. This is especially important in the rural areas where winter road conditions and limited transportation services can disrupt or prevent travel. For example, Sweden has almost twice as many access points per inhabitant as Germany even though Germany has almost ten times the population density as Sweden. This means each library in Sweden has a service area approximately five times as large as the service area of a German library. The number of physical access points per inhabitant in Norway is lower than in Sweden; however, the figure in Norway does not include library boats, buses and small service points. Interestingly, the Nordic countries have many more on-site visits than the other four countries, though no figure is available for Iceland.

To summarize, the figures suggest that the public library as a physical place is of greater importance in the Nordic countries than the other countries. Do the libraries in the Nordic countries offer more on-site services than libraries in the other participating countries? Do the results imply that in the Nordic countries there is a higher level of trust in libraries than in the other countries? How do these differences reflect the public libraries' role in supporting local public spheres? These questions will be reflected upon and addressed in other chapters of this anthology.

\section{Museum Legislation}

The International Council of Museums (ICOM) defines a museum as "a non-profit, permanent institution in the service of society and its development, open to the public, which acquires, conserves, researches, communicates and exhibits the tangible and intangible heritage of humanity and its environment for the purposes of education, study and enjoyment" ("ICOM Definition of a Museum").

Six of the eight participating countries have legislation governing museums; Germany and Norway do not. In Denmark, the stated purpose of the law (2013) is to promote museum work and cooperation with a view to safeguarding Denmark's cultural and natural heritage and securing access to and knowledge of this heritage and its interaction with the rest of the world. Through collection, registration, conservation, research, and communication, museums are tasked with working for the safeguarding of Denmark's cultural and natural heritage, illustrating cultural, natural, and art history, expanding the collections and documentation within their respective areas of responsibility, making the collections and documentation accessible to the general public, making the collections and documentation accessible for research, and communicating the results of such research. 
The Swedish Museum Act (2017) states museums are to contribute to society and its development by promoting knowledge, cultural experiences, and free opinion formation. The law tasks museums with three areas of responsibility. The first, concerning public activities, is that exhibitions and other public activities at a museum shall be knowledge-based and characterized by versatility and openness and shall be accessible to all and adapted to the different conditions of the users. The second, concerning knowledge formation, is that museums shall contribute to research and other knowledge building, among other things by having high competence in its subject area. The third, concerning collection management, is that museums shall actively manage their collections to achieve the objectives of the business.

Icelandic Museum Act (2011) tasks museums with the preservation of Iceland's cultural and natural heritage, ensuring that it is returned unspoiled to future generations, providing access to it and contributing to increased knowledge of the heritage and understanding of its connection to the outside world. The act tasks museums with the collection, registration, preservation, research, exhibitions, and other media to safeguard Iceland's cultural and natural heritage, highlight the country's cultural, natural, and artistic history, strengthen its collection and source collection within its special field, and make its collection and archives accessible to the public and scholars. Furthermore, museums should aim to enhance the quality of life of human beings by fostering understanding of the evolution and status of culture, art, nature or science and aim to ensure the comprehensiveness of their collections. Museums are to operate in the public interest, must be open to the public, and are not for profit.

The Polish Museum Act (1996) states that a museum is a non-profit organizational unit with the aim collecting and preserving tangible and intangible natural and cultural heritage. Furthermore, museums are to inform about the values and contents of their collections, promote fundamental values of the Polish and world history, science and culture, develop cognitive and aesthetic sensitivity, and provide access to the collected holdings.

The Hungarian Library and Museum Act (1997) states, as previously indicated, that the institutions are tasked with the preservation of national cultural traditions and those of national and ethnic minorities, their worthy continuation, improving the staffing, intellectual, and economic conditions for community and individual general cultural activities, and promoting value-oriented activities aimed at improving the quality of life of citizens. Lastly, as stated previously, libraries and museums are to promote the freedom of access to information for all, as it is a fundamental condition for the functioning of the information society and the democratic constitutional state. 
The goals of the Swiss Museums and Collections Act (2010) is to safeguard the important movable cultural property of Switzerland, raise awareness of the cultures of Switzerland, provide museums and collections with a strong identity, collaborate and support other museums, and contribute to the attraction of Switzerland as a place of training and research, economic center, and tourist destination. The Act tasks museums with the preservation of the tangible and intangible heritage, the development of collections with other museums, acquisition of artifacts, presentation themes relating to Swiss society, culture and identity through exhibitions and publications, and promotion of public access to culture.

The mediation and preservation of cultural heritage can be seen as the focus of the museum laws. Cultural heritage may not appear to relate directly to democracy and the public sphere, however, understanding and critical reflection of the cultural heritage is essential for the facilitation of democratic processes. Understanding the past social, economic, and cultural realities forms the basis for decision-making and planning, hence the ability to reflect critically upon cultural heritage underlies democratic processes. Tasking museums with the mediation of cultural heritage is the way the museum laws can be seen to support and connect to democracy and the public sphere. Interestingly, Sweden tasking museums with supporting free opinion formation, versatility, and openness and Iceland tasking museums with ensuring the comprehensiveness of their collections hints at a more inclusive approach, whereas the other countries simply focus on preserving and mediating the cultural heritage.

The Danish and Icelandic laws emphasize the need to relate the cultural heritage to the rest of the world, which may reflect the greater interconnectedness of the world. This may also have something to do with the size of the countries, as Denmark and Iceland are countries with the smallest populations out of the countries with museum laws. Surprisingly, only Hungary includes something in its law about the need for inclusion of minority groups' heritage into the national heritage. Poland's inclusion of the need to "promote fundamental values of the Polish and world history" is ambiguous; does the promotion of world values imply the relation of Poland's cultural heritage to the rest of the world? Does it imply European or Western values, or a broader field?

The promotion and provision of access to information, culture, knowledge, or a combination of these things relate to the basic democratic principles of enlightened citizens and freedom of expression. All the museum laws task the country's museums with making their collections accessible, which can be related back to one of the fundamental values of democracy and the public sphere: equality. However, unlike libraries, not all municipalities or other administrative divisions are 
required to provide a museum service, though museums are commonly found in communities of all sizes, which will be discussed in detail in the next section.

\section{Museum Statistics}

The museum statistics in Table 2.1 are from national sources in the participating countries or from the European Group on Museum Statistics (EGMUS). As previously stated, there are no official statistics available for Iceland; however, data from 2015 were published in a preliminary study on cultural statistics in the Nordic countries. The study was done on behalf of The Nordic Council of Ministers (Kulturstatistik $i$ Norden 2017). These statistics are used in Table 2.1.

Less statistical data are available for the museums than for public libraries, although there is an international ISO standard also for Museum statistics ("ISO 18461:2016"). Funding for museums is often complex and originates from a variety of resources, both public and private. For example, some museums are owned and run by foundations or private entities, but receive public funding. Not all municipalities or other administrative divisions are required to provide a museum service. Interestingly, anybody can start a private business open to the public that aims at displaying a collection of artifacts and call it a museum. There are many local, private owned, and very small museums run by NGOs that are built and rely on voluntary work. This variation in ownership makes it difficult to collect information for national statistics. Consequently, providing a reliable and comprehensive picture of the museum sector is difficult.

The difficulty in obtaining statistics on museums means that the figures in Table 2.1 regarding the number of museums in each country must be interpreted with caution. For example, the statistics for Sweden and Norway only include institutions with professional employees working in positions corresponding to at least one Annual Work Unit (AWU). Museums are not obliged to provide statistics on their operations and use; some provide statistics on a voluntary basis while others do not. In Sweden, for example, it is estimated that about 25 percent of the museums with at least one AWU are not included in the national statistics (Museer 2017 2018, 3).

Despite the ISO Standard for museum statistics, the categorization of museums based on ownership, management, and types of collections differs between the countries and four of the countries do not provide any statistics at all about their collections. This is the reason why there is no information about the collections in Table 2.1. The lack of statistics makes international comparisons very difficult and also makes it difficult to discuss the museum sector in relation to the rest of the LAM field. 


\section{Museums: Services and Use}

The large number of museums in Germany stands out in relation to the other countries, something which may be explained by the fact that Germany has the largest population. The larger population may make possible the provision of and maintenance of museums and museum collections to a greater degree than in the countries with smaller populations. There are also many local museums in Germany, some publicly owned and others privately. A larger proportion of these small, local museums might be included in the statistics than in the other countries. This may be because there is no restriction in Germany, unlike in Sweden and Norway, that only museums with at least one AWU can be included in the national statistics. The institute responsible for the German museum statistics also aims to include all museums, even the very small local museums. The German statistics are still not complete. Twenty-five percent of the museums have not provided statistical data, which means that they are only included in the figure for the total number of museums, but none of the other figures (Statistische Gesamterhebungen den Museen der Bundesrepublik Deutschland für das Jahr 2017, 3).

Private museums are the most common in all countries except Hungary, where publicly run local and regional museums form the largest group. Norway, Sweden, and Poland are the only countries that provide information about running costs. The figures show that the difference in staff density between the countries is small, while there is a huge difference regarding running costs. In Norway, the cost is $94 €$ per inhabitant per year, while in Hungary it is only one fourth of that $(23 €)$. The Polish figures for running costs also appear to be low, though the figures are not completely comparable to the others. The explanation is likely the same as for the staff density in the public libraries. The labor costs are lower in Poland and Hungary than in the other countries, which means that the two countries can spend significantly less money on their museums and still maintain the same staff density. There are no figures from Germany on running costs or staff density, which would have been interesting due to the high number of museums.

Libraries and archives provide access to their collections, but are generally not involved in the interpretation of the content. Contrarily, museums have a strong focus on the interpretation and mediation of their exhibitions, which forms the basis for their public activities. However, not all countries collect statistics on their annual number of exhibitions, and the existing figures are not entirely comparable. The available figures show that Germany is first, which is not surprising considering the high number of museums reported. The figure for Poland, which is second, is also relatively high and well above the figure for Norway, which is third. 
Some museums have entrance fees while archives and libraries generally do not. It would be valuable to see in the museum statistics whether there is a correlation between the proportion of museums with free entry and the number of visits per capita; however, information about entry fees is not included in Table 2.1 because only two countries provide figures. The lack of data here may be because it is complicated for museums to collect statistical data. For example, museums may charge for some arrangements and exhibitions or not for others. Groups, such as children and the elderly, may receive free entry while other groups are required to pay. Currently, many of the museums at the national level in Sweden offer free entry as a result of a parliamentary decision in 2016 that aimed at increasing visits and citizens' overall engagement in cultural activities ("Fri entré infört vid 18 statliga museer.”). In 2019, the Swedish Agency for Cultural Policy Analysis published an evaluation showing that the museums that introduced free admission increased their visiting numbers significantly compared to those that did not (Besöksutveckling för de centrala museerna 2018, 5).

Iceland reports 7.9 museum visits annually per capita, which a very high number in comparison to the other countries. Denmark reports 2.9 and is followed by Sweden and Norway with 2.8 and 2.1 visits respectively. Hungary and Poland are the lowest here with 1.1 visits per capita, which is surprising as Poland has a high number of exhibitions annually; this implies a low number of visitors per exhibition. The figures show that the Nordic countries have high visiting figures in relation to the other countries. This is a similar pattern of use as previously reported for public libraries.

Tourism likely affects the number of visits. Tourists seldom visit archives or public libraries, but they often visit museums, thereby boosting visitor numbers. This is a likely explanation for Iceland's extremely high figure for annual visits per capita. In 2017, Iceland had 7.7 million foreign visitors with at least one overnight stay, which is 23 times the population. In comparison, Germany had about as many foreign visitors as the population and Poland had just under half as many visitors as residents (“Tourism Statistics 2017”).

The national statistics offer little regarding how the digital and online opportunities and resources have affected the collections, services, and use of museums in the respective countries. The Hungarian museum statistics provide some basic figures showing that 56 percent of the museums in Hungary have access to the Internet and that 28 percent use computers for visitors' information purposes ("EGMUS: Complete Data", Hungary 2017). The Swedish museums collect data on the number of unique visits to museum websites (Museer 2017 2018). Norway gives some information about the digitization of museum collections and reports the 
number of visits to Digitaltmuseum.no, which had double the visits in 2017 as 2015 (“Statistikk for museum 2017”).

\section{Archival Legislation}

The word archive has several meanings, of which two are of particular importance for this chapter. First, an archive refers to a collection of primary source records generated by an individual, family or private or public organization; records that have been selected for permanent or long-term preservation due to their cultural, historical or evidentiary value. Second, the word archive refers to an institution with the responsibility to organize, preserve, store, and make accessible archival material (Pearce-Moses 2005, 30). The use of the word archive in this chapter mostly relates to the second definition, therefore, the term "archival institution" will be used. Publicly run archival institutions typically focus on material generated by authorities and public organizations at the national, regional or local level. However, some of the publicly run archival institutions also keep private archives; for example, materials on NGOs, churches, private enterprises, estates, families, and individuals. Privately run archival institutions differ. Many are small, local endeavors built partly or totally by volunteer efforts. Some archival institutions are open to the general public while others restrict access for various legal or cultural reasons.

All the countries participating have archival laws requiring the provision of national archives and the archival laws all have similar purposes related to the preservation of documents of cultural and legal nature and, to varying degrees, making them accessible. The Norwegian Archive Act (1992) states that the purpose of the act is to ensure that archives containing significant cultural or research value or those containing legal or important administrative documentation are preserved and made available for posterity. The Swedish Archive Act (1990) states that archives are part of the national cultural heritage and that they must be preserved, organized, and maintained in order to fulfill the right to access public documents; the need for information pertaining to legal and administrative matters; and the needs of the research.

The Danish Archive Act (2008) states that the purpose of the National Archives is to ensure the preservation of archival records that are of historical value or serve as evidence pertaining to administrative or legal matters that are of importance to citizens and authorities; to ensure the possibility of discarding non-conservation worthy public records in cooperation with the authorities covered by the Act; to 
make archives available to citizens and authorities, including for research purposes; to guide citizens and authorities in the use of archives; and to carry out research and disseminate research results. The Icelandic Public Archives Act (2014) states that the objective of the Act is to safeguard the creation, conservation, and safe handling of public records with a view to protecting the rights of the citizens and the interests of the administration, and ensuring the preservation of the Icelandic people's history.

A common theme running through the archival acts in the Nordic countries is an emphasis on ensuring access to citizens; however, moving away from the Nordic countries to Germany and Switzerland, the emphasis is placed on the carrying out of research, specifically academic research. The German Federal Archives Act (2017) states that the task of the Federal Archives shall be to conserve, utilize, and exploit federal archive material for academic purposes. It shall ensure access to federal archive material while safeguarding private and public interests. However, many of the German states also have archival acts ("Archivrecht/ Archivgesetze"). For example, the act of Thüringen states that everyone has the right to use archival material in public archives (§ 16). The Swiss Federal Act on Archiving (1999) states in the principles section that federal documents that are valuable for legal, political, economic, historical, social or cultural reasons shall be archived and that archiving makes a contribution towards legal certainty and to the continuous and efficient management of administrative activities. In particular, it forms the basis for historical and sociological research.

Hungarian Archive Act (1995) tasks archives with ensuring that current records of public agencies are processed, classified, and made accessible for the administration and public and that current records of any agency or private persons are preserved and made available for posterity in public or open private archives, or as protected archival documents. The law clarifies that the free access to data of public interest and freedom of scientific research be realized together with the protection of fundamental constitutional rights related to personality and to personal data and protection of state secrets, official secrets or business confidential data (Hungarian Archive Act, Section 1). Hungary is one of the few countries that, in the purpose statement, emphasizes the balance between the granting of access and the protection of personal data and confidential state matters. The German Federal Archives Act is the only other act that touches upon this balance in its purpose statement: that archives "shall ensure access to federal archive material while safeguarding private and public interests” (§3). This balance in granting access and protection of personal and state matters might be seen as limitations, albeit necessary and important, when considering how archives can support an informed public discourse and foster the formation of a public sphere. 
The Polish Act on the National Archive Resource and Archives (1983) states that the national archives are to preserve the "materials old" serving as important sources of information pertaining to the historical activities of the Polish State, its bodies, and other State organizational units and its relations with other countries, the development of political, social and economic, professional and religious life, the organization and the development of science, culture and art, as well as on the activities of the local government units and other local organizational units in the past and produced today. The Polish act is the only act to note the role of archives in the development of social and economic life and activities in the political, social, cultural, scientific, economic, professional, and religious realms of society, thus implying an active role that goes beyond preservation and ensuring access.

To summarize, the focus of the archival laws in all of the participating countries is the preservation of and accessibility to historical documents and artifacts. The documentation of the past and accessibility to that documentation ensures citizens', or in some cases scholars', ability to obtain the information needed for understanding and making sense of the present, which is necessary for informed decision-making and the protection of rights, though in some situations access may be limited for the protection of individuals and concerning confidential state matters.

\section{Archival Statistics}

The American Society of Archivists developed a set of principles and guidelines for the collecting of archival statistics, which were approved in 2018, and an ISO standard for archive statistics is in the initial stage of development (Standardized Statistical Measures and Metrics for Public Services in Archival Repositories and Special Collections Libraries, 2017; “ISO 18461:2016”). Currently, no internationally accepted statistical measures exist for archives and little statistical information is available from the participating countries.

Norway and Denmark are the only countries collecting national archival statistics comparable to the statistics collected on libraries. The Norwegian statistics include 61 national, regional, and local archival institutions, and the Danish about 500 national, city, and local archives (Statistikk for arkivinstitusjoner og arkiv i bibliotek og museum 2017, 2018; Statistikdokumentation for Arkiver 2017, 2018). Information is given about the number of full-time employees in national, regional, and local archival institutions, number of visits, written requests for archival documents, and collection growth. The Norwegian statistics include figures about total running costs and the digitization of archival material, while the 
Danish statistics include the number of voluntary workers (Statistikk for arkivinstitusjoner og arkiv i bibliotek og museum 2017, 2018; “Arkiver”). Hungary also has national statistics but unfortunately they were not accessible for the ALMPUB project. None of the other participating countries has comprehensive statistics of the archival sector. Poland and Sweden collect statistical data regarding their national archives, which includes the main and branch locations (Sprawozdanie $z$ działalności Naczelnego Dyrektora Archiwów Państwowych oraz archiwów państwowych w 2017 r., 2018; Kulturstatistik i Norden, 2017, Table 7).

The dearth of national statistics for the archival sector makes comparisons impossible. The figures in Table 2.1 must be considered with caution. Information about the number of state owned national archival institutions is readily available, but information about the number of regional and local archival institutions and for privately run institutions is extremely difficult to find. For example, in Poland, many regional and local archives, such as city archives, are formally parts of the national archive ("Resources in Poland: 1.1 Archives"). The number of archival institutions might be considerably higher than is presented in Table 2.1. To complicate matters further, private archival institutions are generally not covered by archival legislation and many of them are small and sometimes depend on volunteer work. Denmark is exceptional in that it collects statistical data from about 500 different archival institutions, many of them local (Statistikdokumentation for Arkiver 2017, 2018, 4).

Why are there no international standards for archival statistics and why are almost no statistics collected? There is no obvious answer. However, archival institutions have not had the same focus on serving the public, offering cultural experiences or mediating their collections, as have public libraries and museums. Historically, the archival institutions focused primarily on preservation of materials for local, regional, and national governance, management and administration. Researchers also became an important target group more recently. As previously noted, support for administrative and scholarly activities is still strongly emphasized in archival legislation, however the focus has shifted. Currently, the material preserved in the archival institutions is regarded primarily as part of the cultural heritage and the archival acts in all the countries, with exception of the German and Swiss federal acts, strongly emphasize the responsibility to fulfill citizens' right to access public documents. To what extent do citizens access archival documents? How do they do it, through on-site visits or through digital media? Is staffing sufficient to respond to user requests and to manage the rapidly expanding collections? A better, more comprehensive collection of statistics could provide answers to these questions.

There are now ongoing discussions in some countries about improving the archival statistics and an ISO standard is being developed. An official report about 
the archival sector is currently underway in Sweden and will be presented in December 2019. Suggestions on how to organize the collection of archival statistics will be included in this report ("Kommittédirektiv: Översyn av arkivområdet: Dir 2017:106.”).

\section{Archives: Services and Uses}

As a result of the lack of data, it is impossible to draw any overall conclusions about the services and use of archival institutions in the participating countries. Statistics from the national archives could be compared across some of the countries. However, this will say little about LAM institutions' roles as public spheres. The regional and - most of all - the local archives need to be included if that dimension should be taken into account and in order to make comparisons with public libraries and museums. For example, and of relevance to the public sphere, some countries have many private archives connected to local history. In Sweden, many of these regional or local archival institutions are organized as NGOs. They preserve local archival material from a wide spectrum of organizations connected to civil society, for example political, temperance, religious, and ethnic organizations, and the archives work in close cooperation with their member organizations.

Finally, although no conclusions can be drawn about services and use of archival institutions based on archival statistics, one of the surveys of the ALMPUB project that focused on the use of LAM institutions amongst the public presents some data in this respect. The results are discussed in other chapters of this anthology.

\section{Final conclusions}

Public libraries, archival institutions, and museums work with the acquisition, organization, preservation, retrieval, and mediation of information, though they historically have focused on different types of materials. Their collections form parts of our cultural heritage and the LAM-institutions are often referred to as society's collective memory - as “memory institutions". Their work is determined largely by cultural and educational policy decisions and is considered to be of great importance from a democratic perspective. Consequently, their roles as public sphere institutions have many similarities, but can archives, libraries, and museums be considered as a common field of practice, based on the results in this chapter? 
This study has shown that the legislation pertaining to libraries, archives, and museums varies greatly between the participating countries and between the three types of institutions. Library legislation generally came first and in several of the countries as early as the 1920s, when modern public libraries started to develop. Archive laws were established significantly later, in most countries during the 1980s or 1990s, and museum legislation in many cases after the turn of the millennium. There are some exceptions. Norway does not have a museum law yet. The Sweden Library Act (1997) was established relatively late. This may be due to the state, through the conditions for the state grants to public libraries that were introduced as early as 1905, setting frameworks for library services. Hungary has had legislation for all three institutions since the late 1920s.

The federal states of Germany and Switzerland differ from the other countries as the LAM institutions are regulated only partly by federal legislation. There are national archival laws, focusing on federal archival material, a federal law regulating the role of the German national library, and Switzerland has a museum law. Neither Switzerland nor Germany has a federal library law defining the roles and terms of public libraries, as do the other participating countries. It is also important to emphasize that there are many private archives and museums in all countries that are not covered by the legislation. This variation in institutional legislation brings into question how, and to what extent, LAM legislation impacts the activities offered by public libraries, museums, and archival institutions. For example, do public libraries receive more money if there is a law? Would there be fewer if they were not mandated by law? We do not have the answers to these questions, but present important topics for future research to address.

In addition to legislation at the national level, the so-called participatory turn or paradigm that has taken place more broadly in the cultural sector, especially at the policy level, is also important to mention. An in-depth discussion of it is out of the scope of this chapter, but will be addressed in later chapters and is highly relevant for the future of the LAM institutions and their role(s) as public sphere institutions. The cultural sector, within which the LAM institutions are subsumed, has shifted from the experience paradigm to a participatory paradigm (Grøn and Gram 2019). This development of an increasingly participatory culture is one that embraces a bottom-up approach to collection and service provision that facilitates interaction and creation of content by users rather than a top-down approach based on the provision of culture created or collected by professionals (Deodato 2014; Roued-Cunliffe and Copeland 2017).

This has resulted in an emphasis on providing greater support for diversity of expression and the inclusion of marginalized discourses, which has been argued as necessary for achieving a comprehensive and robust public sphere (Fraser 2010). This focus can be seen already in some of the library laws, such as Nor- 
way's that tasks libraries with being meeting places and arenas for dicussion and debate and possibly Sweden and Iceland's museum laws that mandate openness, versitality, and comprehensiveness respectively. Many of the other laws, across the three sectors, can be seen to open up for bottom-up approaches as many of them focus on equal opportunity for expression and the inclusion of diverse perspectives.

On the European level, the Council of the European Union requested a report to identify innovative approaches to the governance of all forms of cultural heritage (e.g. tangible, intangible, digital) that involves stakeholders from all realms of society. This resulted in a collective effort by experts from 27 European countries to create a handbook for professionals and led to the publication of Participatory Governance of Cultural Heritage; Report of the OMC (Open Method of Coordination) Working Group of Members States' Experts; European Agenda for Culture; Workplan for Culture 2015-2018. The participatory governance approach has been used as a working method in the field of culture since 2017 in the framework of the European Agenda for Culture. Of the participating countries in the ALMPUB project, Switzerland, Norway and Iceland are not member states in the EU; however, Norway, for example and in addition to its library law, has relatively new cultural policy goals based on a bottom-up approach (Meld St. 8 (2018-2019) Report to the Storting (white paper), 2019). The creation of this report and the incorporation of participatory governance as a working method suggest that the participatory paradigm is gaining momentum within the European context.

Looking forward, this new participatory turn may facilitate the formation of a more unified LAM sector, but it may also create tensions as these intitutions have historically been characterized by top-down approaches and, as publicly funded insitutions, may experience pressure to carry out state agendas. This is a growing concern as nationalist ideas have grown in strength all over Europe in recent years and a raging debate has arisen, particularly in Poland and Hungary, about the nationalist orientation of cultural policy and an increased ideological control of cultural institutions. An important question is how this development will affect the LAM field. As we could see, Hungary has a very dense network of local public libraries compared to most of the other ALMPUB countries, because of its numerous small municipalities. Publicly run local and regional museums are the most common in Hungary, although most of them are private in the other countries. To what extent will these publicly run local ALM institutions be expected to serve as the government's tool in the disseminating of a nationalist cultural policy at the local level and to what extent could that affect their public access to free information?

This study has also shown that the collection of statistics is very different when it comes to archives, libraries, and museums. For example, there are no 
national archival statistics except for Norway and Denmark. Norway is the only country that has had a common governmental agency aimed at the development of the whole LAM field. "ABM-utvikling” existed between 2003 and 2009 and will be discussed and analyzed in two other chapters of this anthology. However, it is an interesting question, whether Norway's complete statistics could be explained by the fact that for a period there was a clearer focus on LAM as a common field than in many other countries.

Finally, the main purpose of the ALMPUB project has been to study LAM institutions' role as public spheres in the age of digitalization. A few of the participating countries give some information in their statistics about the digitization of collections and use of digital media in museums. Most of the countries present figures about the downloading of e-books in public libraries. Norwegian archival statistics present figures about the digitization of archival material. Other than these statistics, the statistics are still focused on traditional media and give very limited information about digital media, services and use. This leaves us with the question of how the LAMs can (or will) employ digitalization and ICT in their role as public sphere institutions, or, in the face of increased online activity, will the institutions' ability to facilitate physical meetings and discussions be the way in which they break through online echo chambers and filter bubbles and nurture the dialogue necessary for the realization of a robust and inclusive public sphere?

\section{References}

\section{LAM-legislation}

Act LXVI of 1995 on Public Records, Public Archives, and the Protection of Private Archives [Hungary]. Accessed August 22, 2019. https://www.ecoi.net/en/file/local/1067797/227_ tmpphpFMFCXI.pdf.

Act CXL. of 1997 on the Protection of Cultural Goods, Museum Institutions, Public Library Services and Community Culture [Hungary]. Accessed August 22, 2019. https://net.jogtar.hu/ jogszabaly?docid=99700140.TV.

"Archivrecht/Archivgesetze." Arkivschule Marburg. Accessed August 22, 2019. https://www. archivschule.de/DE/service/archivrecht/.

Danish Archive Act. Accessed August 22, 2019. https://www.retsinformation.dk/forms/r0710. aspx?id=183862.

Danish Library Act. Accessed August 22, 2019. https://www.retsinformation.dk/forms/r0710. aspx?id=145152.

Danish Museum Act. Accessed August 22, 2019. https://kum.dk/english/services/legislation/ archives-museums-and-cultural-heritage/museum-act/.

German Federal Archives Act. Accessed August 22, 2019. https://www.bundesarchiv.de/EN/ Navigation/Meta/About-us/Legal-Bases/Federal-Archives-Act/federal-archives-act.html. 
Icelandic Library Act. Accessed August 22, 2019. https://www.government.is/media/menntamala raduneyti-media/media/frettir2014/Thyding-bokasafnalog-april-2015-Lokagerd-a-vef.pdf.

Icelandic Museum Act. Accessed August 22, 2019. https://www.althingi.is/lagas/nuna/2011141. $\mathrm{html}$.

Icelandic Public Archives Act. Accessed August 22, 2019. https://skjalasafn.is/files/docs/ ThePublicArchivesAct-in-Iceland-No-77-2014.pdf.

Norwegian Archive Act. Accessed August 22, 2019. https://lovdata.no/dokument/NL/lov/199212-04-126.

Norwegian Public Library Act. Accessed August 22, 2019. https://lovdata.no/dokument/NL/lov/ 1985-12-20-108.

Polish Act on the National Archive Resource and Archives. Accessed August 22, 2019. https: //www.global-regulation.com/translation/poland/3354040/the-act-of-14-july-1983-onthe-national-archive-resource-and-archives.html.

Polish Library Act. Accessed August 22, 2019. https://www.portaloswiatowy.pl/organizacjapracy/ustawa-z-27-czerwca-1997-r.-o-bibliotekach.-tekst-jedn.-dz.u.-z-2018-r.-poz.-57416532.html.

Polish Museum Act. Accessed August 22, 2019. http://prawo.sejm.gov.pl/isap.nsf/DocDetails. xsp?id=WDU19970850539.

"Stand der Entwicklung in den Bundesländern." Deutscher Bibliotheksverband. Accessed August 22, 2019. https://www.bibliotheksverband.de/dbv/themen/bibliotheksgesetze/bundeslae nder/stand-der-entwicklung.html.

Swedish Archive Act. Accessed August 22, 2019. https://www.riksdagen.se/sv/dokument-lagar/ dokument/svensk-forfattningssamling/arkivlag-1990782_sfs-1990-782.

Swedish Library Act. Accessed August 22, 2019. https://www.riksdagen.se/sv/dokument-lagar/ dokument/svensk-forfattningssamling/bibliotekslag-2013801_sfs-2013-801.

Swedish Museum Act. Accessed August 22, 2019. https://www.riksdagen.se/sv/dokumentlagar/dokument/svensk-forfattningssamling/museilag-2017563_sfs-2017-563.

Swiss Federal Act on Archiving. Accessed August 22, 2019. https://www.admin.ch/opc/en/ classified-compilation/19994756/index.html.

Swiss Museums and Collections Act. Accessed August 22, 2019. https://www.global-regulation. com/translation/switzerland/2974889/rs-432.30-federal-law-of-june-12\%252c-2009-onthe-museums-and-collections-of-confederation- $\% 2528$ law-on-museums-and-collections $\%$ 252c-cml\%2529.html.

\section{Other material}

“A Magyarországi Könyvtárak Statisztikai Adatai [Statistical Data of Hungarian Libraries].” n.d. Könyvtári Intézet [The Library Institute]. Accessed October 12, 2019. http://www.ki.oszk. hu/informacioszolgaltatas/magyarorszagi-konyvtarak-statisztikai-adatai.

“Archives of Hungary." Association of Hungarian Archivists. Accessed October 12, 2019. http: //www.archivportal.hu/en/archives-of-hungary/.

“Arkiver." Statistics Denmark. Accessed October 12, 2019. https://www.statistikbanken.dk/ 10391.

Årsredovisning 2017 för riksarkivet. Stockholm: Swedish National Archives, 2018. https: //riksarkivet.se/Media/pdf-filer/Riksarkivet-arsredovisning-2017.pdf. 
Besöksutveckling för de centrala museerna 2018: redovisning av regeringsuppdraget "Besöksutveckling för vissa statliga museer 2018" 2019-05-02. Stockholm: Swedish Agency for Cultural Policy Analysis, 2019. https://kulturanalys.se/wp-content/uploads/2019/05/ Besoksutveckling-for-de-centrala-museerna-2018_v2.pdf.

Bibliotek 2017: offentligt finansierade bibliotek. Stockholm: National Library of Sweden, 2018. https://www.kb.se/download/18.42b0ca55163848cb4b5227/1531819095573/ Biblioteksstatistik_2017.pdf.

“Culture in 2017." Statistics Poland. Accessed October 12, 2019. https://stat.gov.pl/obszarytematyczne/kultura-turystyka-sport/kultura/kultura-w-2017-roku, 2,15.html.

“Data of Museums 2000-." Hungarian Central Statistical Office. Accessed October 12, 2019. https://www.ksh.hu/docs/eng/xstadat/xstadat_annual/i_zkk005b.html.

Deodato, J. “The Patron as Producer: Libraries, Web 2.0, and Participatory Culture”. Journal of Documentation, 70, no. 5, 734-758, 2014.

“EGMUS: Complete Data." EGMUS - European Group of Museum Statistics. Accessed October 12, 2019. https://www.egmus.eu/nc/en/statistics/complete_data/.

“European Countries by Population.” Worldometers. Accessed October 12, 2019. https://www. worldometers.info/population/countries-in-europe-by-population/.

European Union. Participatory Governance of Cultural Heritage: Report from the OMC (Open Method of Coordination) Working Group of Member States' Experts: European Agenda for Culture; Workplan for Culture 2015-2018. Luxembourg: Publications Office of the European Union, 2018. https://apo.org.au/sites/default/files/resource-files/2018/04/aponid189996-1238346.pdf.

Fraser, N. "Rethinking the Public Sphere: A Contribution to the Critique of Actually Existing Democracy (1992)". In Gripsrud, J. and M. Eide (eds), The Idea of the Public Sphere: A Reader, pp. 127-149. Lanham, MD: Lexington Books, 2010.

"Fri entré infört vid 18 statliga museer”. Swedish Government. Accessed October 12, 2019. https://www.regeringen.se/artiklar/2016/02/fri-entre-infort-vid-18-statliga-museer/.

Grøn, R. and L. K. Gram. "Deltagelsens paradoks - samlingens rolle i den brugerinddragende formidling". The Nordic Journal of Cultural Policy, (2), 2019.

"Héraðsskjalasöfn [Regional Archives]." National Archives of Iceland. Accessed October 12, 2019. https://skjalasafn.is/heradsskjalasofn.

"Historisk statistikk for folkebibliotek, 2017." National Library of Norway. Accessed October 12, 2019. https://kunnskapsbase.bibliotekutvikling.no/statistikk/statistikk-for-norskebibliotek/folkebibliotek/historisk-statistikk-for-folkebibliotek/.

"ICOM Definition of a Museum." ICOM - International Council of Museums. Accessed October 12, 2019. http://archives.icom.museum/definition.html.

“ISO 2789:2013, International Library Statistics." International Organization for Standardization. Accessed October 12, 2019. https://www.iso.org/obp/ui/\#iso:std:iso:2789:ed-5:v1: en.

“ISO 18461:2016, International Museum Statistics." International Organization for Standardization. Accessed October 12, 2019. https://www.iso.org/obp/ui/\#iso:std:iso:18461:ed-1: v1:en.

"ISO/CD 24083, Information and Documentation - International Archives Statistics." International Organization for Standardization. Accessed October 12, 2019. https://www.iso.org/ standard/77765.html. 
“Kommittédirektiv: Översyn av arkivområdet: Dir 2017:106." Swedish Government. Accessed October 12, 2019. http://www.sou.gov.se/wp-content/uploads/2018/03/ Kommittédirektiv-Översyn-av-arkivområdet-för-delning.docx.pdf.

Kulturstatistik i Norden: en förstudie. Stockholm: Kulturanalys Norden, 2017. https:// kulturanalysnorden.se/wp-content/uploads/2017/04/kulturstatistik-i-norden.pdf.

Meld St. 8 (2018-2019) Report to the Storting (white paper): The Power of Culture. Summary. Oslo: Norwegian Ministry of Culture. https://www.regjeringen.no/contentassets/ 9778c28ab1014b789bbb3de0e25e0d85/en-gb/pdfs/stm201820190008000engpdfs.pdf.

“Museen 2017." Bundesamt für Statistik [Switzerland]. 2017. Accessed October 12, 2019. https: //www.bfs.admin.ch/bfs/de/home/statistiken/kultur-medien-informationsgesellschaftsport/kultur/museen.html.

Museer 2017. Stockholm: Swedish Agency for Cultural Policy Analysis, 2018. https:// kulturanalys.se/wp-content/uploads/2018/06/museer-2017-webb.pdf.

Museer i Norden. Stockholm: Kulturanalys Norden, 2018. https://kulturanalysnorden.se/wpcontent/uploads/2018/06/Museer-i-Norden-webb_NY.pdf.

“Museums.” Statistics Denmark. Accessed October 12, 2019. https://www.dst.dk/en/Statistik/ emner/kultur-og-kirke/museer-og-kulturarv/museer.

“Öffentliche Bibliotheken Gesamtstatistik, Kerndaten 2017.” DBS - Deutsche Bibliotheksstatistik. Accessed October 12, 2019. https://wiki1.hbz-nrw.de/pages/viewpage.action?pageld= 99811337\&preview=/99811337/311230480/oeb_bund_2017.pdf.

“Öffentliche Bibliotheken in den Städten (Gemeinden Ab 10,000 Einwohnern): Daten 2017." Bundesamt für Statistik [Switzerland]. Accessed October 12, 2019. https://www.bfs.admin. $\mathrm{ch} / \mathrm{bfs} / \mathrm{de} /$ home/statistiken/kultur-medien-informationsgesellschaft-sport.assetdetail. 5746971.html.

Pearce-Moses, R. A Glossary of Archival and Records Terminology. Chicago: The Society of American Archivists, 2005. http://files.archivists.org/pubs/free/SAA-Glossary-2005.pdf.

“Public Libraries." Statistics Denmark. Accessed October 12, 2019. https://www. statistikbanken.dk/10391.

“Real GDP per Capita [2017]." Eurostat. Accessed October 12, 2019. https://ec.europa.eu/ eurostat/databrowser/view/sdg_08_10/default/table?lang=en.

"Resources in Poland: 1.1 Archives." School of Advanced Study, University of London. Accessed October 12, 2019. https://port.sas.ac.uk/mod/book/view.php?id=1887\&chapterid=2022.

Roued-Cunliffe, H. and A. Copeland. Participatory Heritage. London: Facet, 2017.

Sprawozdanie z Działalności Naczelnego Dyrektora Archiwów Państwowych Oraz Archiwów Państwowych w 2017 r. [Report on the Activities of the Polish State Archives in 2017]. Warsaw: General Directorate of State Archives, 2018. https://www.archiwa.gov.pl/files/ SPRAWOZDANIE_2017.PDF.

Standardized Statistical Measures and Metrics for Public Services in Archival Repositories and Special Collections Libraries. Society of American Archivists \& Association of College and Research Libraries, 2017. https://www2.archivists.org/standards/standardizedstatistical-measures-and-metrics-for-public-services-in-archival-repositories.

“Statistik der schweizer Städte 2019." Bundesamt für Statistik. 2019. Accessed October 12, 2019. https://www.bfs.admin.ch/bfs/de/home/statistiken/kataloge-datenbanken/ publikationen.assetdetail.8086839.html.

Statistikdokumentation for Arkiver 2017. Copenhagen: Statistics Denmark, 2018. https://www. $\mathrm{dst.dk/da/Statistik/dokumentation/statistikdokumentation/arkiver.}$ 
Statistikdokumentation for Museer 2017. Copenhagen: Statistics Denmark, 2018. https://www. dst.dk/da/Statistik/dokumentation/statistikdokumentation/museer.

Statistikk for arkivinstitusjoner og arkiv i bibliotek og museum 2017. Oslo: Arkivverket, 2018. https://www.arkivverket.no/arkivutvikling/tall-og-data-statistikk/arkivstatistikken-amb/ tall-og-analyser-fra-2017\#!\#block-body-2.

Statistikk for museum 2017. Oslo: Arts Council Norway, 2018. https://www.kulturradet.no/ documents/10157/4c3ab521-3498-4c80-8942-413b205bdeba.

Statistische Gesamterhebungen den Museen der Bundesrepublik Deutschland für das Jahr 2017. Berlin: Institut für Museumsforschung, 2018. https://www.egmus.eu/fileadmin/ national_Data/German_Publications/mat72.pdf.

The Public Library Service: IFLA/UNESCO Guidelines for Development. IFLA Publications 97. München: Saur, 2001. www.ifla.org/files/assets/hq/publications/archive/the-publiclibrary-service/publ97.pdf.

“Tourism Statistics 2017.” Eurostat. Accessed October 12, 2019. https://ec.europa.eu/eurostat/ statistics-explained/index.php?title=Tourism_statistics.

Verband deutscher Archivarinnen und Archivare (ed.). Archive in Deutschland, Österreich und der Schweiz: Adressenverzeichnis 2017-2018. Münster: Ardey, 2017.

The authors wish to thank Henrik Jochumsen, Casper Hvenegard Rasmussen, Andreas Vårheim, Ragnar Audunson, Hans-Christoph Hohbom, Karsten Schuldt, Máté Tóth, Ágústa Pálsdóttir, and Anna Mierzecka for information about LAM legislation and statistics from their respective countries and for constructive and insightful comments on the text. 


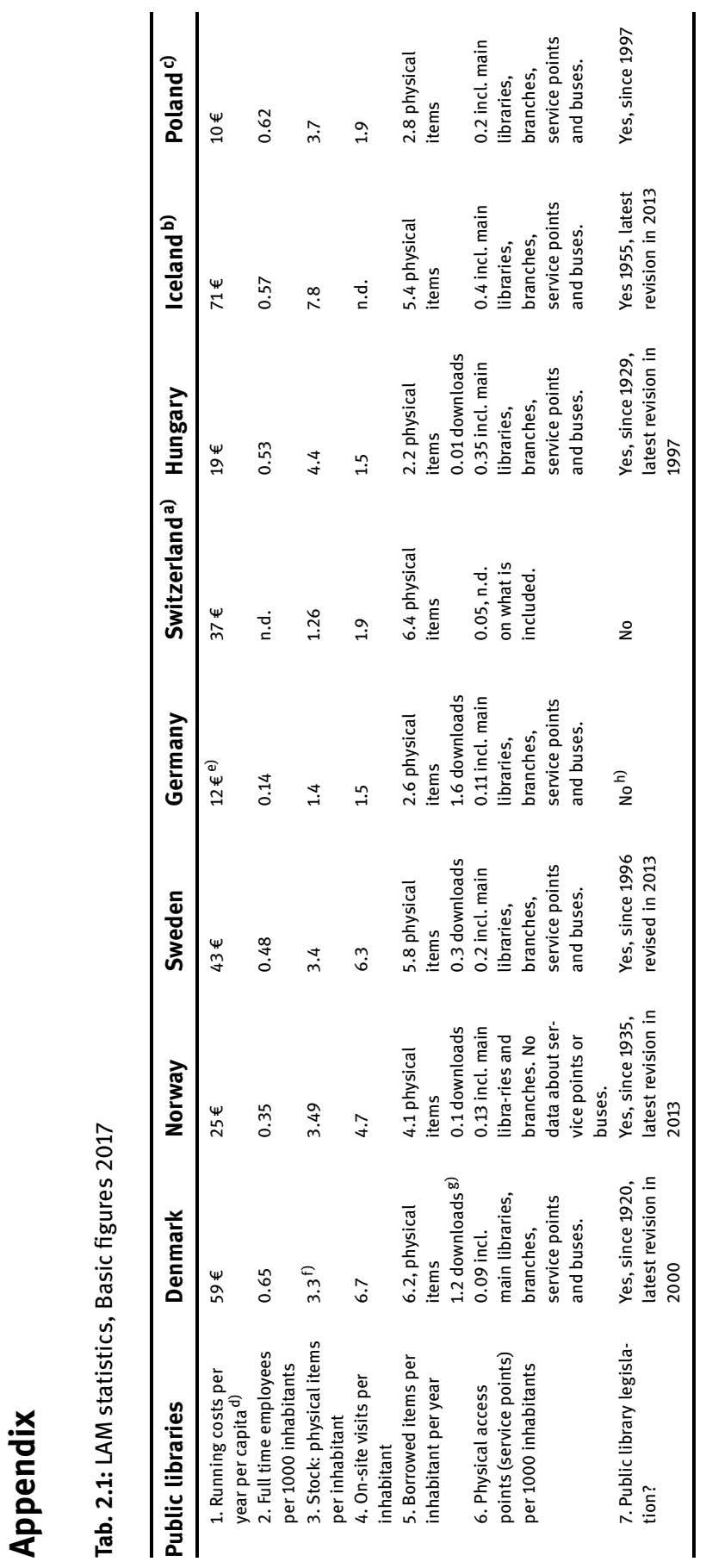




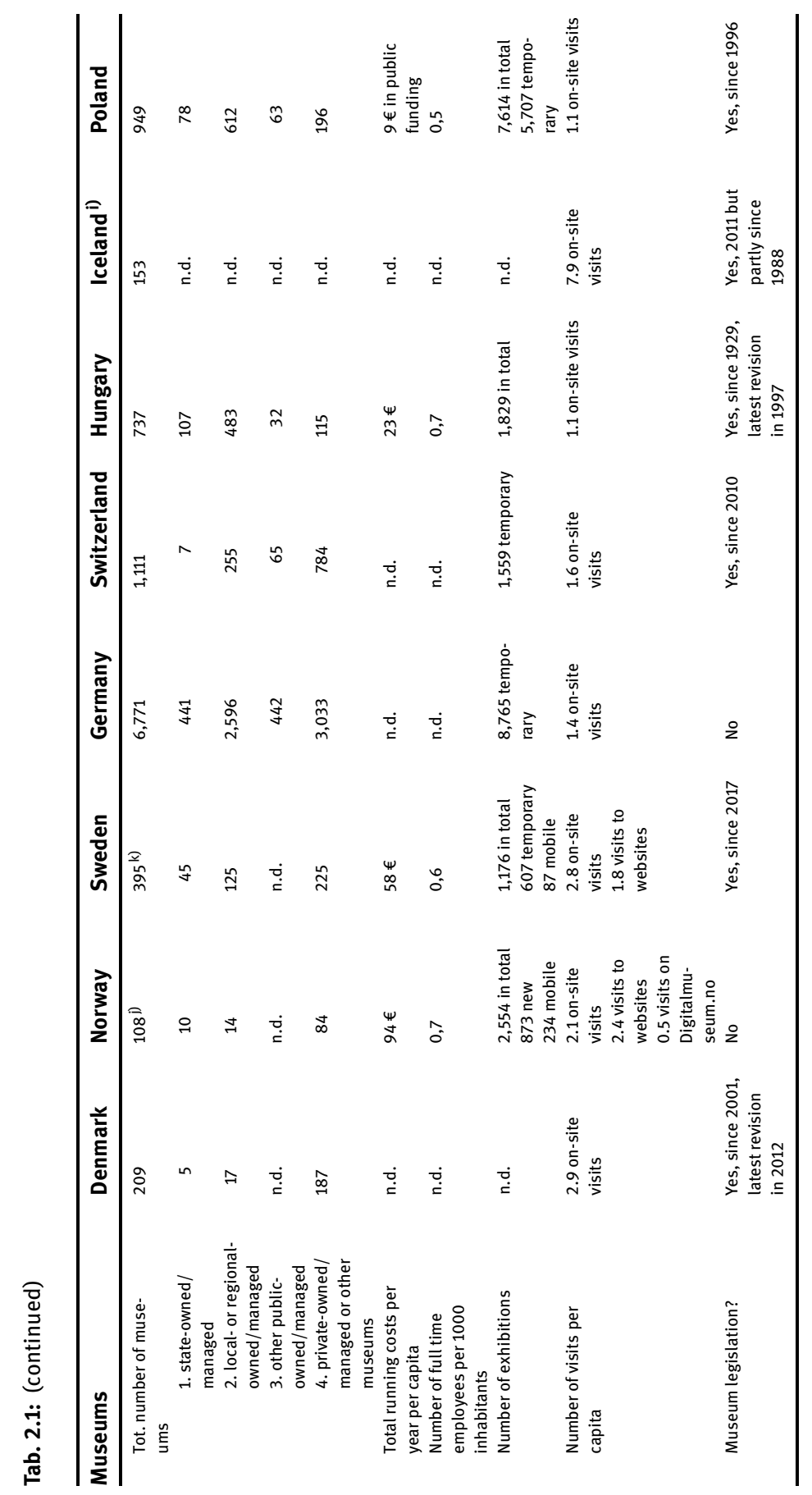




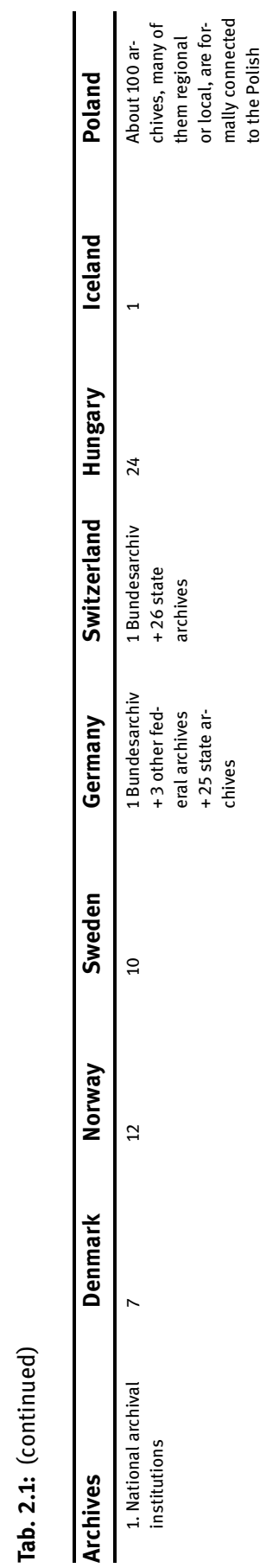

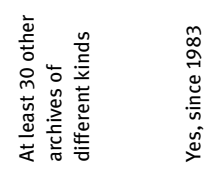

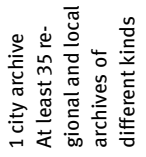

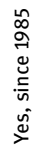

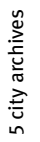

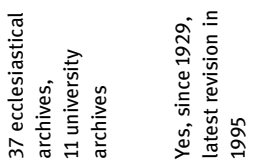

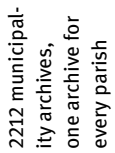

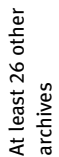

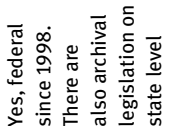

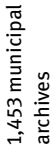

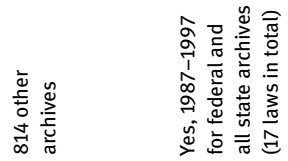

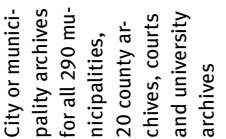

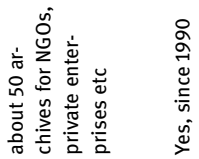

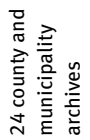

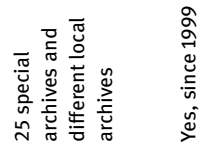

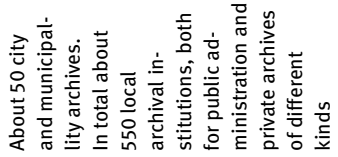

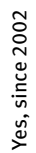
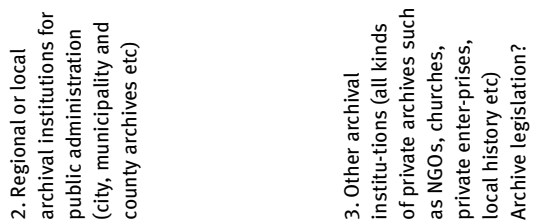


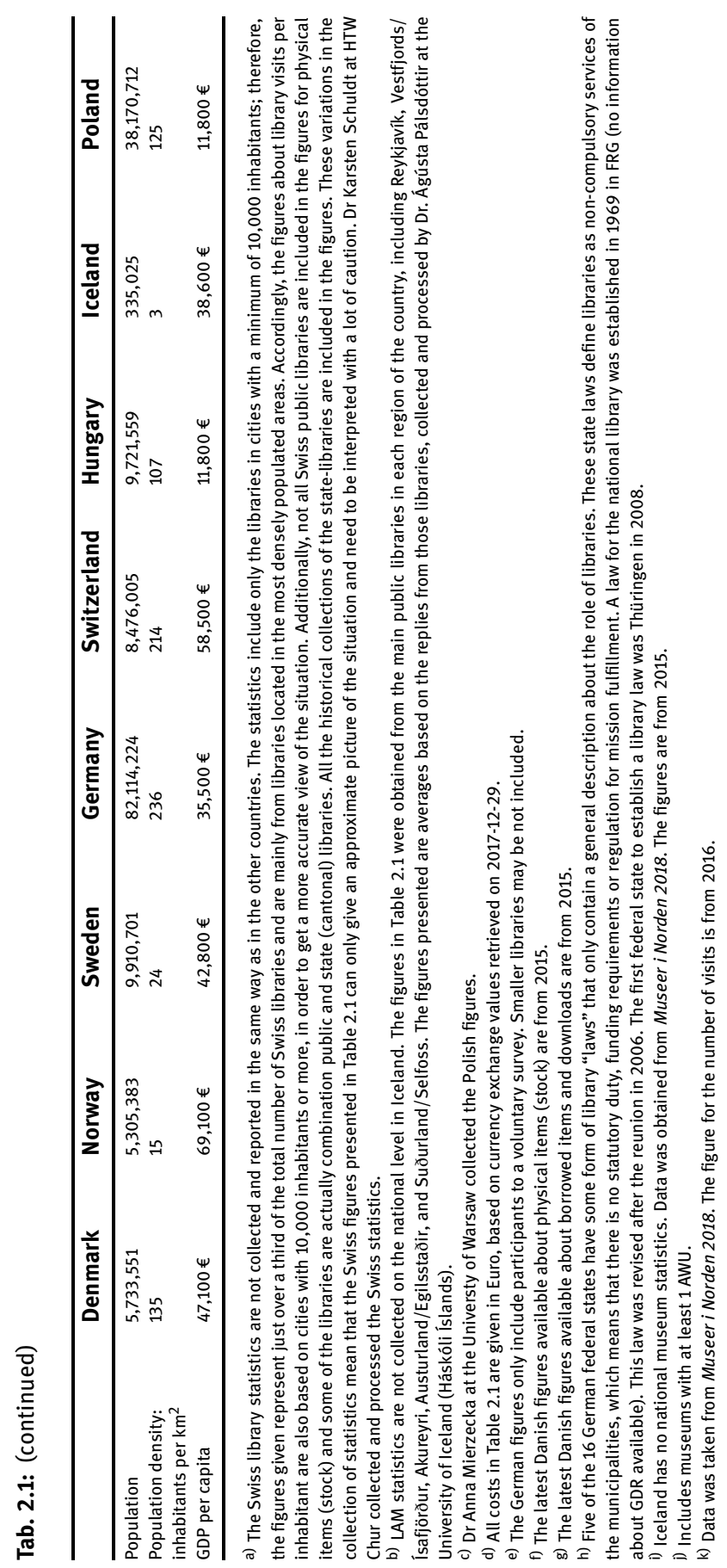

